\title{
Homocysteine, trace elements and oxidant/antioxidant status in mild cognitively impaired elderly persons: a cross-sectional study
}

\author{
HAJAR NEGAHDAR ${ }^{1}$, SEYED REZA HOSSEINI ${ }^{2}$, HADI PARSIAN ${ }^{2, *}$, FARZAN KHEIRKHAH ${ }^{2}$, \\ ABBAS MOSAPOUR ${ }^{1}$, SORAYA KHAFRI ${ }^{3}$, ASEFEH HAGH HAGHIGHI ${ }^{1}$ \\ ${ }^{1}$ Department of Biochemistry and Biophysics, Babol University of Medical Sciences, Babol, Iran \\ ${ }^{2}$ Social Determinant of Health Research Center, Health Research Institute, Babol University of Medical Sciences, Babol, Iran \\ ${ }^{3}$ Department of Social Medicine, Faculty of Medicine, Babol University of Medical Sciences, Babol, Iran
}

\begin{abstract}
Introduction. Mild cognitive impairment (MCI) is the prodromal stage of Alzheimer's disease (AD), so identification of the related risk factors can be helpful. There are controversial data regarding the serum oxidant/antioxidant status, trace elements and homocysteine (Hcy) as effective parameters in this disease, therefore the status of these factors was determined in this study.

Methods. One hundred-twenty elderly persons with cognitive impairment and 120 elderly healthy persons who were differentiated using Mini-mental state examination (MMSE) participated in this study. The patients were divided into mild and moderate-to-severe cognitive impairment group. Serum antioxidant/oxidant, copper $(\mathrm{Cu})$, manganese $(\mathrm{Mn})$, zinc $(\mathrm{Zn})$ and Hcy concentrations were measured using routine methods.

Results. Oxidant and antioxidant levels increased and decreased based on the severity of the disease and were higher and lower in patients than in control group, respectively $(p<0.001)$. With adjusting for age, gender and education, significant difference in Hcy levels was not observed. There was no significant difference in trace elements levels among groups.

Conclusions. Results confirmed the association between oxidative damage with increasing the severity of cognitive impairment. These factors may be involved in the etiology of cognitive impairment and AD. Identification of such biomarkers is important to select appropriate treatment goals before the onset of irreversible clinical signs.
\end{abstract}

Key words: Alzheimer disease, oxidative stress, mild cognitive impairment, homocysteine, trace element.

\section{INTRODUCTION}

Dementia usually caused by Alzheimer's disease $(\mathrm{AD})$ is an irreversible disorder, which can induce important damages to the normal nervous system. Since mild cognitive impairment (MCI) is a prodromal stage of $\mathrm{AD}$ and patients with $\mathrm{AD}$ are likely susceptible to develop dementia, identification of various changeable biochemical and molecular parameters in these patients is very important. Cognitive impairment has three stages as: mild, moderate and severe cognitive impairment; that transition from mild to severe stage of MCI is associated with increasing risk of developing dementia [1]. As we know, any dyshomeostasis of biochemical parameters can lead to disease. Fortunately, it is possible to modify the levels of some biochemical factors through various therapeutic interventions. MCI patients have the potential to meet the preventive and therapeutic interventions and ultimately the prevention of the progression to $\mathrm{AD}$ [1]. There are various reports regarding molecular etiology of AD. Researchers have shown that in $\mathrm{AD}$, important macromolecules such as proteins [2, 3], DNA [4] and lipids [5] in the cells of hippocampus and parahippocampal gyrus may be damaged. It seems that all of these damages are under the influence of oxidative stress (OS) [2-5]. It is suggested that increase in the levels of various free radicals is associated with pathogenesis of $A D$ and these deleterious molecules are so powerful to induction of progression of MCI to $\mathrm{AD}$. In the results of free radicals attack on macromolecules, these molecules may lose their structure and function.

Formation of the amyloid- $\beta(\mathrm{A} \beta)$, a soluble peptide with 42 amino acids that concentrated in senile plaque is a fundamental characteristic of the $\mathrm{AD}$ [6]. There is a strong relationship between $\mathrm{A} \beta$ formation and levels of free radicals. Some studies suggested a toxic role for $A \beta$ on neurons [7-10], but in an unexpected theory, an antioxidant role for $\mathrm{A} \beta$ is also proposed. According to this theory, an increase in the production of early $\mathrm{A} \beta$ deposits is a compensatory response to occurrence of OS [11, 
12]. It is believed that the antioxidant activity of $\mathrm{A} \beta$ depends on its concentration $[13,14]$. In fact, micromolar range of $A \beta$ might be toxic. In addition, $\mathrm{A} \beta$ can strongly bind to metals ions (such as Zinc $(\mathrm{Zn})$ and Coper $(\mathrm{Cu}))[15]$ and, theoretically, this chelating property can prevent the oxidation of biomolecules by these metals. Despite numerous beneficial and biological roles of trace elements in metabolism, some of them can be toxic in excessive amount. Some transient metals are able to stimulate the formation of free radicals and these events are probably senior of pathological lesions that occurr in $\mathrm{AD}$ [16]. In addition to OS and transient metals, it has been suggested that hyperhomocysteinemia contribute in this process. A significant correlation between the risk of developing MCI (and dementia) and high levels of homocysteine (Hcy) (that is due to the low levels of folic acid and vitamins B6 and B12) has been reported [17-19]. The molecular mechanism of Hcy toxicity is not fully known yet. It has been suggested that hyperhomocysteinemia can induce hypomethylation via the various enzymes such as methyl transferase [20]. In addition, its role in increasing the OS status has been suggested [21].

Reporting data regarding the oxidant/antioxidant imbalance, trace elements dyshomeostasis or hyperhomocysteinemia is controversial and to some degree inconclusive. Therefore, the aim of this study was to determine the serum status of oxidant/antioxidant, Hcy and $\mathrm{Cu} / \mathrm{Zn} /$ manganese $(\mathrm{Mn})$ as contributing parameters in $\mathrm{MCI}$ in an elderly population.

\section{MATERIAL AND METHODS}

\section{Study population}

The population of this study was elderly persons from Amirkola Health and Aging Project (AHAP) [22] in which people aged $\geq 60$ years old were recruited for health study. According to the AHAP study, written informed consent was obtained after the oral explanation of the study. Among 1616 elderly persons that contributed in AHAP project, 300 elderly patients had MCI. Diagnosis of MCI patients was according to the results of MiniMental State Examination (MMSE) score system. Cognitive impairment degree for each participant was identified using MMSE score. We categorized the persons according to the resulted score into two classes: normal and MCI. A person with a MMSE score between 0 to 24 was considered as MCI and one who had the score $\geq 25$ was considered as normal. Ultimately, the cognitive impaired persons were divided into two categories; 1 : mild (called as MCI I, score from 20-24), and 2: moderate to severe cognitive impairment (called as MCI II, score from 0-19). All patients who had a history of drugs that affect the Hcy levels such as metformin, cholestyramine, methotrexate, nicotinic acid, pyridoxine, theophylline, L-dopa, cyclosporine and cobalamin and persons with stroke and smoking history were excluded from the current study. Moreover, we excluded all persons with kidney dysfunction and malabsorption diseases. Finally, 120 elderly patients with cognitive impairment remained and participated in the present study. One-hundred-twenty healthy gender and age matched persons were selected randomly as the control group from the AHAP. This study was approved as a quality assurance project by institutional ethics committee of Babol university of medical science.

\section{Laboratory measurements}

Blood samples for analysis of biochemical parameters were taken from all the subjects and the serum was separated. Resulted serum was divided into $0.2 \mathrm{ml}$ micro tubes and stored frozen at -80 degrees Celsius until analysis.

Serum Hcy concentration was measured by using the commercial kits (Axis-Shield Diagnostics Ltd, FHRWR 100/200/1000 UK.) with automated Autoanalyser (Hitachi 912). In this method, briefly free Hcy was converted to cystathionine by the cystathionine beta-synthase and excess serine. The cystathionine was then broken down to Hcy, pyruvate and ammonia. Pyruvate was converted to lactate via lactate dehydrogenase with $\mathrm{NADH}$ as coenzyme. The rate of NADH conversion to $\operatorname{NAD}^{+}(\triangle \mathrm{A} 340 \mathrm{~nm})$ was directly proportional to the concentration of Hcy.

Serum $\mathrm{Mn}$ and $\mathrm{Cu}$ concentrations were determined through atomic absorption spectrophotometery method (PG 990, China) equipped with a graphite furnace. Samples were diluted 1/20 with $\mathrm{HNO}_{3} 0.1 \%$ for $\mathrm{Cu}$ determination. EDTA $100 \mu \mathrm{g} / \mathrm{L}$ (as modifier) and $\mathrm{HNO}_{3} \quad 0.1 \%$ were used for analysis of $\mathrm{Mn}$ (final dilution factor $=3$ ). Then $10 \mu \mathrm{L}$ of the diluted samples was injected into the graphite furnace. Working standard solutions were prepared from the stock standards $(1000 \mathrm{mg} / \mathrm{L}$, Merck) of $\mathrm{Cu}$ and $\mathrm{Mn}$ for calibration curve.

The serum $\mathrm{Zn}$ concentration was measured with Biorex diagnostics kit (BXC0462, UK) using spectrophotometer (UNICO 2100). Zn in the sample was chelated by 5-Br-PAPS (2-(5-bromo-2-pyri- 
dylazo)-5-(N-propyl-N-sulfopropylamino)-phenol) present in the reagent. The formation of this complex was measured at a wavelength of $560 \mathrm{~nm}$.

In the present study, malondialdehyde (MDA) as a side product of lipid peroxidation was measured by using the thiobarbituric acid reactive substances (TBARS) assay. MDA levels were evaluated using thiobarbituric acid as the major reagent in TBARS assay. Based on the spectrophotometric method, the condensation of one molecule of MDA with two molecules of Thiobarbituric acid and the elimination of two molecules of $\mathrm{H}_{2} \mathrm{O}$ lead to the formation of a pink complex measured at $320 \mathrm{~nm}$.

We used ferric reduction antioxidant power (FRAP) assay as a method to evaluate the antioxidant power spectrophotometrically. FRAP assay measures the ability of serum for reduction of ferric ions to ferro in acidic $\mathrm{pH}$. Ferric ions were converted to ferro and the production of colored complex of ferro tripyridyl triazine was measured in wavelength $=593 \mathrm{~nm}$.

\section{Statistical analysis}

Biochemical variable values were skewed and therefore all data was $\log$ transformed before analysis. This helps us to reduce the effect of outliers on statistical analysis. One-Way ANOVA and Tukey post hoc test were used to evaluate the differences among the means of parameters. The relationship between factors was assessed using Pearson's correlation test and related P-value.

The studied population was categorized into two groups: educated and uneducated persons. Multiple linear regression analysis was used for assessing the biochemical factors affected MMSE scores. The effect of disease on changes in parameters was determined by analysis of covariance and age, gender and education were considered as confounder factors. The multinomial multiple logistic regression model was used to estimate the effect of parameters' changes on various intensities of disease. The statistical analysis was performed with SPSS version 16.0 and in all analysis P-values $<0.05$ were considered significant.

\section{RESULTS}

Demographic, clinical and biochemical variables of the studied groups are presented in Table 1. Age and education levels, but not gender, were statistically different in three included groups $(\mathrm{P}<0.001)$ and the control group was younger and more educated than MCI I and MCI II groups. In addition, no statistical difference was observed between two genders in the value of biochemical parameters. The serum levels of total anti-oxidant, before adjusting for potential confounding factors (age, gender and education) were significantly lower in patients than in control subjects and showed the decrease of gradient from MCI I to MCI II patients. An opposite pattern and trend were found about serum MDA levels. No correlation was seen among the biochemical variable levels with demographic and clinical characteristics in each person (Table 1).

Univariate analysis adjusted for potential confounding factors (age, gender and education) showed that the level of total antioxidant and oxidant biomarkers remained significantly lower and higher, respectively, in the patients versus healthy group. Furthermore, no differences were observed among three groups in $\mathrm{Hcy}, \mathrm{Zn}$ and $\mathrm{Mn}$ and $\mathrm{Cu}$ levels. In the MCI II group, $\mathrm{Cu}$ concentration indicated a slight decrease in comparison with $\mathrm{MCI}$ I in the crude data.

In linear regression analysis (backward method) in which age, gender and education were considered as covariate, we observed that age, education, FRAP and MDA concentrations were highly correlated with MMSE worsening and uneducated persons had lower MMSE scores in comparison with the educated ones. In addition, getting older was associated to the worsening of the MMSE scores. Also, higher and lower serum levels of MDA and FRAP, respectively, were related to the worsening of the MMSE score. Scatter plot confirmed these results for the FRAP and MDA concentrations (Fig. 1).

Table II indicates the results of the multinomial logistic regression analysis with FRAP and MDA concentrations as effective variables. According to the likelihood ratio test, the variables that were able to discriminate these three included groups were: age, education, total antioxidant and oxidant biomarkers. The first contrast (control group $v s$. MCI I) indicated that besides the effect of age (for each year, OR $=1.061 ; \mathrm{p}<0.001$ ) and education (being uneducated, OR: 6.604; $\mathrm{p}<0.001$ ), FRAP and MDA were able to discriminate MCI I individuals from the healthy controls. In the second contrast (controls $v s$. MCI II) we observed that the effect of age (for each year, $\mathrm{OR}=1.166 ; \mathrm{p}<0.001$ ) and education (being uneducated, OR: 9.89; $\mathrm{p}<0.001)$ in addition to the FRAP and MDA were effective parameters for discrimination of MCI II individuals than the healthy ones. 
Table I

Comparison of mean values of demographic, clinical and biochemical variable in included persons

\begin{tabular}{lcccc}
\hline \multicolumn{1}{c}{ Indications } & $\begin{array}{c}\text { Control } \\
(\mathbf{1 2 0})\end{array}$ & $\begin{array}{c}\text { MCI I } \\
(\mathbf{5 7})\end{array}$ & $\begin{array}{c}\text { MCI II } \\
(\mathbf{6 3})\end{array}$ & P-value \\
\hline Age & $67.7 \pm 6.9$ & $71.4 \pm 7.3$ & $77.0 \pm 7.3$ & $<0.001$ \\
\hline Gender $(\%$ male) & 50 & 56.1 & 44.4 & 0.441 \\
\hline $\begin{array}{c}\text { Education number }(\%) \\
\text { uneducated } \\
\text { educated }\end{array}$ & $50(65.4)$ & $49(86)$ & $58(92.1)$ & $<0.001$ \\
& $70(34.6)$ & $8(14)$ & $5(7.9)$ & $<0.001$ \\
\hline FRAP $(\mu \mathrm{mol} / \mathrm{L})^{*} 10^{3 \mathrm{a}}$ & $1.4 \pm 0.4$ & $1.2 \pm 0.3$ & $0.9 \pm 0.3$ & $<0.001$ \\
\hline TBARS $(\mu \mathrm{mol} / \mathrm{L})^{\mathrm{a}}$ & $4.5 \pm 2.7$ & $6.8 \pm 3.6$ & $8.4 \pm 3.4$ & 0.880 \\
\hline $\mathrm{Zn}(\mu \mathrm{g} / \mathrm{dl})^{\mathrm{a}}$ & $72.8 \pm 31.9$ & $80.2 \pm 39.9$ & $0.98 \pm 0.4$ & 0.068 \\
\hline $\mathrm{Cu}(\mathrm{ppm})^{\mathrm{a}}$ & $0.88 \pm 0.3$ & $1.0 \pm 0.4$ & $14.2 \pm 4.7$ & 0.363 \\
\hline $\mathrm{Mn}(\mathrm{ppb})^{\mathrm{a}}$ & $13.5 \pm 5.3$ & $14.4 \pm 5.7$ & $23.6 \pm 24.7$ & 0.009 \\
\hline $\mathrm{Hcy}(\mu \mathrm{mol} / \mathrm{L})^{\mathrm{a}}$ & $16.3 \pm 7.0$ & $18.3 \pm 7.9$ & & \\
\hline
\end{tabular}

${ }^{\mathrm{a}} \mathrm{Log}$-transformation was performed for all biochemical variables.

Data are presented as mean \pm standard deviation.

Abbreviations: FRAP - Ferric reduction antioxidant power; Hcy - homocysteine; TBARS - Thiobarbituric acid reactive substances; MCI I - mild cognitive impairment; MCI II - moderate to severe cognitive impairment.

Table II

Multiple multinomial logistic regression model

\begin{tabular}{|c|c|c|c|c|c|c|c|c|}
\hline & \multicolumn{4}{|c|}{ Control (120) vs. MCI I (57) } & \multicolumn{4}{|c|}{ Control (120) vs. MCI II (63) } \\
\hline & \multirow[t]{2}{*}{$\overline{\mathrm{B}}$} & \multirow[t]{2}{*}{ P-value } & \multicolumn{2}{|c|}{$95 \%$ Confidence Interval } & \multirow[t]{2}{*}{ B } & \multirow[t]{2}{*}{ P-value } & \multicolumn{2}{|c|}{ 95\% Confidence Interval } \\
\hline & & & $\begin{array}{l}\text { Lower } \\
\text { limit }\end{array}$ & $\begin{array}{l}\text { Upper } \\
\text { limit }\end{array}$ & & & $\begin{array}{l}\text { Lower } \\
\text { limit }\end{array}$ & $\begin{array}{l}\text { Upper } \\
\text { limit }\end{array}$ \\
\hline FRAP & -0.002 & $<0.001$ & 0.997 & 0.999 & -0.004 & $<0.001$ & 0.994 & 0.998 \\
\hline MDA & 0.241 & $<0.001$ & 1.1 & 1.47 & 0.307 & $<0.001$ & 1.152 & 1.603 \\
\hline Age & 0.059 & $<0.001$ & 1.008 & 1.115 & 0.154 & $<0.001$ & 1.10 & 1.23 \\
\hline Education & 1.88 & $<0.001$ & 2.69 & 16.20 & 2.29 & $<0.001$ & 3.01 & 32.56 \\
\hline
\end{tabular}

Abbreviations: MDA - Malondialdehyde; others, see Table I.

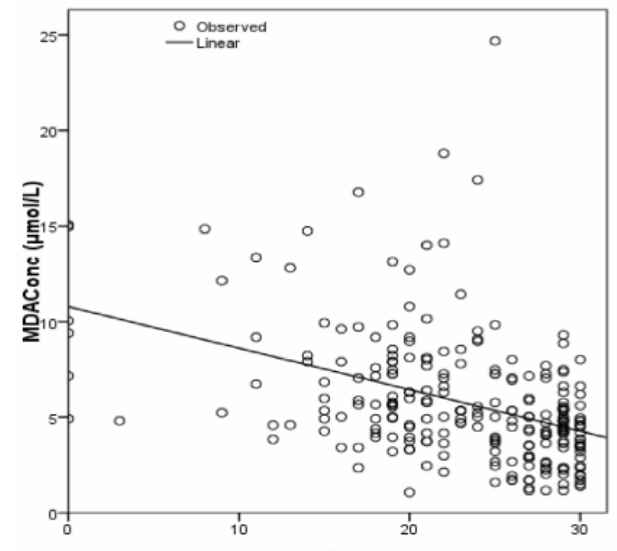

(a)

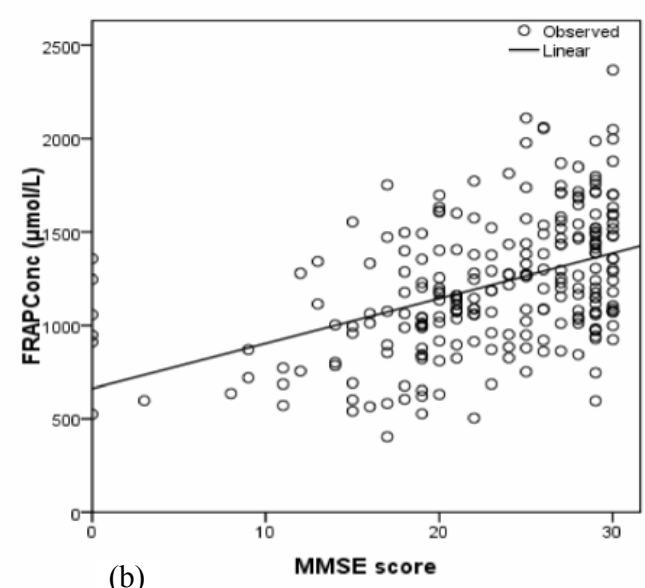

(b)

Figure 1. Scatter plots for, (a) MDA and (b) FRAP levels on MMSE scores.

\section{DISCUSSION}

MCI reflects a transitional state between normal aging and decline in cognitive abilities related to early dementia [23]. At this stage of disease, despite the presence of AD hallmarks, the clinical signs are not seen [24]. Numerous studies have suggested that $\mathrm{OS}$ is associated with $\mathrm{AD}$ and sometimes it is considered as a causal factor in AD pathogenesis. Our results strongly supported the relationship between increased OS and cognitive impairment in our population. Based on our findings, MDA levels showed a gradient change from stage I to stage II cognitive impairment and both groups had a significantly higher concentration of MDA than the control group. These results indicated that 
lipid peroxidation was increased along with the severity of cognitive impairment. The result of serum antioxidant levels showed that antioxidant capacity was reduced with a negative gradient in both patients groups in comparison to the healthy control. OS may be the early event in $\mathrm{AD}$, before the onset of clinical symptoms in the patient's body [11].

Nunomura et al. reported that an increase in OS was associated with reduction in the $A \beta$ deposits [12]. They also reported that a $40-56 \%$ decrease in levels of 8-hydroxyguanosine in neurons containing neurofibrillary tangles than neurofibrillary tangles free neurons [11]. It seems that in these conditions, use of antioxidant supplements may be helpful for preventing the cognitive decline, as Shelly et al. reported [25].

It seems that the equilibrium of $\mathrm{Zn}$ and $\mathrm{Cu}$ is very important for preventing the formation and accumulation of $A \beta$ in $A D$ patient [26]. We also examined serum status of $\mathrm{Zn}, \mathrm{Mn}$ and $\mathrm{Cu}$ in patients and control groups. There were statistically no differences in concentrations of these trace elements among the included persons. In crude data, an increase in the level of these metals was found in the patient groups. Massie et al. and Maynard et al. in their researches reported that the $\mathrm{Cu}$ increases with aging in the brains of mouse models $[27,28]$. Maynard declared that an increase in $\mathrm{Cu}$ contents of human brain may also be visible [26]. It has been suggested that the mean concentration of $\mathrm{Cu}$ in the serum or plasma may not exactly reflect the amount of this metal in patient's brain. In some AD patients in spite of normal levels of $\mathrm{Cu}$ in the plasma or serum, the increase of $\mathrm{Cu}$ contents in cerebrospinal fluid was observed [29]. In the current study, the observed trend in crude data may only reflect the onset of metal dyshomeostasis or probably is due to the aging process.

Studies suggested that amyloid precursor protein and amyloid peptide might interact with $\mathrm{Cu}$ in aggregated plaques and possibly contribute in the AD pathogenesis through OS[30-33]. On the contrary, in the crude data, we observed a decrease in serum $\mathrm{Cu}$ levels in MCI II patients in comparison with MCI I and healthy elderly persons. This may be caused by $\mathrm{Cu}$ chelating property of the newly formed $A \beta$ in the MCI II group as compensatory response to occurrence of OS and as a try for improving the hypothesis antioxidant function of the cells. Surely, this needs to clarify and approve in another study with larger sample size.

Hcy that its normal range are determined in various population [34], mostly is known as a risk factor for stroke [35] and atherosclerosis [36], but it is suggested to have a role in neurodegenerative diseases. Zhao et al. in their report has also introduced Hcy as a factor in the pathogenesis of $\mathrm{AD}$ and suggested that this amino acid is able to increase OS in this disease [37]. According to the fact that there was a slight increase in Hcy concentration with aging and since the MCI patients were older than the control group, the elevated concentrations of Hcy may be caused by aging.

\section{CONCLUSIONS}

Cognitive impairment is a multi-factorial syndrome and various conditions may cause it. In the present study only the status of oxidative damage was analyzed and the findings confirmed the association between oxidative damage and increasing severity of cognitive impairment. These factors may be involved in the etiology of cognitive impairment and AD. Therefore, identification of such biomarkers is very important for selecting that appropriate treatment goals before the onset of irreversible clinical signs of the disease. In addition, identification of the exposed persons and families can be useful for both individuals and the health system.

Acknowledgments. This project was part of grant No. 1808 supported by the Deputy of Research and Technology of Babol University of Medical Sciences, Babol, Iran. We are thankful to Vice-Chancellery of Health for their assistance in conducting the project.

Conflict of interests: None.

\section{ABBREVIATIONS}

AD - Alzheimer's disease

MCI - mild cognitive impairment

OS - oxidative stress

A $\beta$ - amyloid- $\beta$

MDA - malondialdehyde

TBARS - Thiobarbituric Acid Reactive Substances

FRAP - Ferric Reduction Antioxidant Power
Hcy - Homocysteine

MMSE - Mini-Mental State Examination

MCI I - mild cognitive impairment stage I

MCI II - mild cognitive impairment stage II and III or moderate to severe cognitive impairment

AHAP - Amirkola Health and Aging Project 
Introducere. Disfuncția uşoară cognitivă (MCI) este stadiul prodromal al bolii Alzheimer (AD) aşadar identificarea factorilor de risc poate fi utilă. $\hat{I} n$ literatură sunt date controversate legate de statusul antioxidant seric, micronutrienți şi homocisteina (HCy) drept parametrii de analizat în AD aşadar acești factori au fost determinați in acest studiu.

Materiale şi metode. Au fost recrutați 120 de pacienți vârstnici cu disfuncție cognitivă şi 120 de pacienți vârstnici sănătoşi. Acestora le-a fost administrat Minimental state examination (MMSE) şi pacienții cu disfuncție cognitivă au fost impărțiți în grup cu disfuncție uşoară şi disfuncție moderat severă. Au fost analizate nivelurile serice ale cuprului, ale manganului, zincului, Hcy precum şi statusul antioxidant seric.

Rezultate. Nivelurile oxidanților au fost mai mari la pacienții cu disfuncție cognitivă, iar nivelurile antioxidanților au fost semnificativ mai mici în cadrul acestui grup comparat cu martorii sănătoşi $(p<0.001)$. După ajustarea pentru vârstă, gen, statusul educațional nu s-au observat diferențe semnificative între nivelurile serice ale Hcy între cele două grupuri. Nu au fost diferențe semnificative nici între concentrațiile microelementelelor.

Concluzii. Rezultatele confirmă asocierea dintre stresul oxidativ şi apariția disfuncției cognitive. Acesta ar putea fi implicat în etiologia AD. Identificarea unor astfel de biomarkeri este importantă pentru selecția tratamentului adecvat.

Correspondence to: Hadi Parsian, Social Determinant of Health Research Center,

Health Research Institute , Babol University of Medical Sciences,

Ganjafrooz Ave, Babol, Iran.

Telephone +98-1132190569, Fax: +98-1132190569

E-mail: hadiparsian@yahoo.com

\section{REFERENCES}

1. BURNS A, ZAUDIG M. Mild cognitive impairment in older people. Lancet 2002; 360(9349):1963-1965.

2. AKSENOV MY, AKSENOVA MV, BUTTERFIELD DA. Protein oxidation in the brain in Alzheimer's disease. Neuroscience 2001; 103(2):373-383.

3. BUTTERFIELD DA, CM LAUDERBACK. Lipid peroxidation and protein oxidation in Alzheimer's disease brain: potential causes and consequences involving amyloid $\beta$-peptide-associated free radical oxidative stress. Free Radic Biol Med 2002; 32(11): 1050-1060.

4. LI JC, KAMINSKAS E. Deficient repair of DNA lesions in alzheimer's disease fibroblasts. Biochem Biophys Res Commun 1985; 129(3):733-738.

5. SAYRE LM, ZELASKO DA, HARRIS PL. 4-Hydroxynonenal-derived advanced lipid peroxidation end products are increased in Alzheimer's disease. J Neurochem 1997; 68(5):2092-2097.

6. HARDY J, ALLSOP D. Amyloid deposition as the central event in the aetiology of Alzheimer's disease. Trends Pharmacol Sci $1991 ; \mathbf{1 2}: 383-388$.

7. ZHANG YW, THOMPSON R, ZHANG H. APP processing in Alzheimer's disease. Mol Brain 2011; 4(1):3.

8. DYRKS T, DYRKS E, HARTMANN T. Amyloidogenicity of beta A4 and beta A4-bearing amyloid protein precursor fragments by metal-catalyzed oxidation. J Biol Chem 1992; 267(25):18210-17.

9. K HENSLEY, JM CARNEY, MP MATTSON. A model for beta-amyloid aggregation and neurotoxicity based on free radical generation by the peptide: relevance to Alzheimer disease. Proc Natl Acad Sci 1994; 91(8):3270-3274.

10. BUTTERFIELD DA, HENSLEY K, HARRIS M. $\beta$-Amyloid peptide free radical fragments initiate synaptosomal lipoperoxidation in a sequence-specific fashion: Implications to Alzheimer's disease. Biochem Biophys Res Commun 1994; 200(2):710-715.

11. NUNOMURA A, PERRY G, ALIEV G, HIRAI K, TAKEDA A, BALRAJ EK et al. Oxidative damage is the earliest event in Alzheimer disease. J Neuropathol Exp Neurol 2001; 60(8):759-767.

12. NUNOMURA A, CHIBA S, LIPPA CF, CRAS P, KALARIA RN, TAKEDA A et al. Neuronal RNA oxidation is a prominent feature of familial Alzheimer's disease. Neurobiol Dis 2004; 17(1):108-113.

13. MOREIRA PI, SANTOS MS, OLIVEIRA CR, SHENK JC, NUNOMURA A, SMITH MA et al. Alzheimer disease and the role of free radicals in the pathogenesis of the disease. CNS Neurol Disord Drug Targets 2008; 7(1):3-10.

14. KONTUSH A, BERNDT C, WEBER W, AKOPYAN V, ARLT S, SCHIPPLING S et al. Amyloid- $\beta$ is an antioxidant for lipoproteins in cerebrospinal fluid and plasma. Free Radic Biol Med 2001; 30(1):119-128. 
15. LOVELL MA, ROBERTSON JD, TEESDALE WJ, CAMPBELL JL, MARKESBERY WR. Copper, iron and zinc in Alzheimer's disease senile plaques. J Neurol Sci 1998; 158(1):47-52.

16. Castellani RJ, Rolston RK, Smith MA. Alzheimer disease. Dis Mon 2010; 56(9):484.

17. RAMOS MI, ALLEN LH, MUNGAS DM, JAGUST WJ, HAAN MN, GREEN R et al. Low folate status is associated with impaired cognitive function and dementia in the Sacramento Area Latino Study on Aging. Am J Clin Nutr 2005; 82(6):13461352.

18. QUADRI P, FRAGIACOMO C, PEZZATI R, ZANDA E, FORLONI G, TETTAMANTI M et al. Homocysteine, folate, and vitamin B-12 in mild cognitive impairment, Alzheimer disease, and vascular dementia. Am J Clin Nutr 2004; 80(1):114-122.

19. TUCKER KL, QIAO N, SCOTT T, ROSENBERG I, SPIRO A. High homocysteine and low B vitamins predict cognitive decline in aging men: the Veterans Affairs Normative Aging Study. Am J Clin Nutr 2005; 82(3):627-635.

20. MILLER, A.L. The methionine-homocysteine cycle and its effects on cognitive diseases. Altern Med Rev 2003; 8(1):7-19.

21. BOLDYREV A. Molecular mechanisms of homocysteine toxicity and possible protection against hyperhomocysteinemia. Recent advances on nutrition and the prevention of Alzheimer's disease. Trivandrum, India: Transworld Research Network 2010; $127-43$.

22. HOSSEINI SR, CUMMING RG, KHEIRKHAH F, NOOREDDINI H, BAJANI M, MIKANIKI E et al. Cohort profile: The Amirkola health and ageing project (AHAP). Int J Epidemiol 2014; 43(5):1393-400

23. PETERSEN RC, NEGASH S. Mild cognitive impairment: an overview. CNS Spectr 2008; 13(1):45.

24. PRICE JL, KO AI, WADE MJ, TSOU SK, MCKEEL DW, MORRIS JC. Neuron number in the entorhinal cortex and CA1 in preclinical Alzheimer disease. Arch Neurol 2001; 58(9):1395-1402.

25. GRAY SL, HANLON JT, LANDERMAN LR, ARTZ M, SCHMADER KE, FILLENBAUM GG. Is antioxidant use protective of cognitive function in the community-dwelling elderly? Am J Geriatr Pharmacother 2003; 1(1): 3-10.

26. MAYNARD CJ, BUSH AI, MASTERS CL, CAPPAI R, LI QX. Metals and amyloid- $\beta$ in Alzheimer's disease. Int J Exp Pathol 2005; 86(3):147-159.

27. MASSIE HR, AIELLO VR, IODICE AA. Changes with age in copper and superoxide dismutase levels in brains of C57BL/6J mice. Mech Ageing Dev 1979; 10(1):93-99.

28. MAYNARD CJ, CAPPAI R, VOLITAKIS I, CHERNY RA, WHITE AR, BEYREUTHER K et al. Overexpression of Alzheimer's disease amyloid- $\beta$ opposes the age-dependent elevations of brain copper and iron. J Biol Chem 2002; 277(47):44670-44676.

29. ROOS PM, VESTERBERG O, NORDBERG M. Metals in motor neuron diseases. Exp Biol Med (Maywood) 2006; 231(9):1481-1487.

30. HA C, RYU J, PARK CB. Metal ions differentially influence the aggregation and deposition of Alzheimer's $\beta$-amyloid on a solid template. Biochemistry 2007; 46(20):6118-6125.

31. ZUCCONI GG, CIPRIANI S, SCATTONI R, BALGKOURANIDOU I, HAWKINS DP, RAGNARSDOTTIR KV. Copper deficiency elicits glial and neuronal response typical of neurodegenerative disorders. Neuropathol Appl Neurobiol 2007; 33(2):212-225.

32. LUTSENKO S, BARNES NL, BARTEE MY, DMITRIEV OY. Function and regulation of human copper-transporting ATPases. Physiol Rev 2007; 87(3):1011-1046.

33. TAYLOR JP, HARDY J, FISCHBECK KH. Toxic proteins in neurodegenerative disease. Science 2002; 296(5575):1991-1995.

34. GOLBAHAR J, BARARPOUR H. Normal range of total plasma homocysteine concentrations in southern Iran. IJMS 2003; 28:139-42.

35. COLLABORATION H.S. Homocysteine and risk of ischemic heart disease and stroke: a meta-analysis. JAMA 2002; 288(16):2015-2022.

36. TEMPLE ME, LUZIER AB, KAZIERAD DJ. Homocysteine as a risk factor for atherosclerosis. Ann Pharmacother 2000; 34(1):57-65.

37. ZHAO L, YAN Y, WANG Y, CAI Z. Homocysteine Contributes to Pathogenesis by Oxidative stress for Alzheimer's disease. Aging and Neurodegeneration 2013; 1:1.

Received June 19, 2015 